\title{
Abdominal hysterectomy: analysis of clinico-histopathological correlation in Western Rajasthan, India
}

\author{
Dinesh Pal Yadav ${ }^{1 *}$, Ramgopal Yadav $^{2}$, Indra Bhati ${ }^{1}$
}

\begin{abstract}
${ }^{1}$ Department of Obstetrics and Gynecology, Dr. S.N. Medical college, Jodhpur, Rajasthan, India
${ }^{2}$ Department of Cardiothoracic Surgery, SMS Medical College, Jaipur, Rajasthan, India
\end{abstract}

Received: 12 January 2017

Accepted: 08 February 2017

\author{
*Correspondence: \\ Dr. Dinesh Pal Yadav, \\ E-mail: dineshpalyadav2@gmail.com
}

Copyright: () the author(s), publisher and licensee Medip Academy. This is an open-access article distributed under the terms of the Creative Commons Attribution Non-Commercial License, which permits unrestricted non-commercial use, distribution, and reproduction in any medium, provided the original work is properly cited.

\begin{abstract}
Background: Hysterectomy is the most common gynecological surgery done in the females worldwide as it provides definitive cure to a wide range of gynecological diseases, both benign and malignant. The indications to perform this major surgery should always be justified and the pathology should be proved histopathologically. Histopathological analysis and review is mandatory to evaluate the appropriateness of the hysterectomy.

Methods: A retrospective, longitudinal study was conducted in the Department of Obstetrics and Gynecology, UMAID Hospital, Dr. S.N. M.C. Jodhpur (Raj.) during October 2014 to March 2015.Total 105 cases were studied during this period. The study included all women undergoing planned abdominal hysterectomy. Data was recorded on proformas, including demographic characteristics and clinical features. Hysterectomy specimens were saved in $10 \%$ formalin and sent to the Department of Pathology. Histopathology reports were analyzed and compared with the indications of surgery to draw various informative conclusions.

Results: Of 105 cases, 55(52.38\%) were in the age group of 41 - 50, which comprised the commonest age group undergoing the surgery. Maximum women (95\%) those underwent hysterectomy were multiparous. Most common preoperatively clinical diagnosis was leiomyoma uterus which was diagnosed clinically and sonographically in 51(48.57\%) cases. On Histopathological examination, the commonest pathology, similar to clinical impression, was found to be Leiomyoma at $50.48 \%(\mathrm{n}=53)$. Adenomyosis $(21.90 \%)$ was detected as Second most common pathology. Histopathological confirmation of pre-operative diagnosis was $89 \%$ for malignancy, $96 \%$ for fibroids, $100 \%$ for adenomyosis, $100 \%$ for pelvic inflammatory disease.

Conclusions: There was a high correlation when the clinical diagnosis was a fibroid, adenomyosis and ovarian mass. Every hysterectomy specimen should be subjected to histopathological examination because it is mandatory for conforming diagnosis and ensuring optimal management, in particular of malignant disease.
\end{abstract}

Keywords: Abdominal hysterectomy, Histopathological, Leiomyoma

\section{INTRODUCTION}

Hysterectomy is the second most frequently performed major surgical procedure on women all over the world especially peri and post-menopausal, second only to caesarean. ${ }^{1}$ Hysterectomy is an effective treatment option for many conditions like fibroid, abnormal uterine bleeding, endometriosis, adenomyosis, uterine prolapse, pelvic inflammatory disease and cancer of reproductive organ when other treatment options are contraindicated or have failed, or if the woman no longer wishes to retain her menstrual and reproductive function. About $70-80 \%$ of hysterectomies are performed by the abdominal approach. ${ }^{2}$ Historically Charles Clay performed the first subtotal hysterectomy in Manchester England in 1843 and the first Total abdominal hysterectomy was done in 1929. ${ }^{3}$ 
Histopathological analysis of the hysterectomy specimens is mandatory for diagnostic purposes and to assess the pattern of lesions common in the uterus and adenexa in a particular population. The importance of histopathological examination is seen, especially in patients with genital cancer, where the adjuvant treatment is dependent upon the grade and extent of the invasion of the disease. The diagnosis of adenomyosis is established only by histopathological examination, while DUB is a diagnosis of exclusion. Some of the patients may be suspected of having a malignancy on pre-operative assessment, histopathological examination may help in ruling out this suspicion. Whether every hysterectomy is necessary is a topic of debate and appropriate indications for hysterectomy are subject of substantial disagreement and there should be a periodical audit of this issue for its indications. $^{4}$

\section{METHODS}

This retrospective study was conducted in the Department of Obstetrics and Gynecology, UMAID Hospital, Dr. S.N. M.C. Jodhpur (Raj.) during October 2014 to March 2015.Total 105 cases were studied during this period.

The study included all women undergoing planned abdominal hysterectomy. Data was recorded on proformas, including demographic characteristics and clinical features. Only one dominant diagnosis was considered and documented as the indication for the procedure.

Hysterectomy specimens were saved in $10 \%$ formalin and sent to the Department of Pathology, Dr. S.N. M.C. Jodhpur (Raj.) .Histopathology reports were analyzed and compared with the indications of surgery to draw various informative conclusions.

\section{RESULTS}

A total of 105 total abdominal hysterectomy were done between October 2014 to March 2014. The age groups that underwent hysterectomy for various indications ranged from 20-75 years. Of 105 cases, 55(52.38\%) were in the age group of 41-50 which comprised the commonest age group undergoing the surgery. $29.52 \%$ were in the age group of 31-40 years (Table 1). Maximum women (95\%) those underwent hysterectomy were multiparous. Most of them $(67.61 \%)$ belongs to the rural areas (Table 1). Out of 105, 56(53.33\%) were attended the outdoor with the menstruation related excessive irregular or frequent bleeding problems and second most common chief complaints was pain abdomen which was present in $36(34.28 \%$ ) women (Table 2).

Table 1: Demographic picture of patients.

\begin{tabular}{|c|c|c|c|c|c|c|}
\hline \multirow{2}{*}{ Age(years) } & $<20$ & $21-30$ & $31-40$ & $41-50$ & $51-60$ & $>61$ \\
\hline & $1(0.95 \%)$ & $6(5.71 \%)$ & $31(29.52 \%)$ & $55(52.38 \%)$ & $9(8.57 \%)$ & $3(2.85 \%)$ \\
\hline \multirow[t]{2}{*}{ Parity } & 0 & 1 & $2-3$ & $>3$ & & \\
\hline & $1(0.95 \%)$ & $5(4.76 \%)$ & $61(58.09 \%)$ & $38(36.19 \%)$ & & \\
\hline \multirow[t]{2}{*}{ Residence } & Rural & Urban & & & & \\
\hline & $71(67.61 \%)$ & $34(32.38 \%)$ & & & & \\
\hline
\end{tabular}

Most common preoperatively clinical diagnosis was leiomyoma uterus which was diagnosed clinically and sonographically in $51(48.57 \%)$ cases.

Table 2: Distribution according to clinical symptoms.

\begin{tabular}{|l|l|l|}
\hline Symptoms & $\begin{array}{l}\text { No. of } \\
\text { cases }\end{array}$ & Percentage \\
\hline Menstrual related problems & 56 & $53.33 \%$ \\
\hline Pain abdomen & 36 & $34.28 \%$ \\
\hline Urinary symptoms & 1 & $0.95 \%$ \\
\hline $\begin{array}{l}\text { Excessive discharge per } \\
\text { vaginum }\end{array}$ & 2 & $1.90 \%$ \\
\hline Backache & 5 & $4.76 \%$ \\
\hline Lump abdomen & 3 & $2.85 \%$ \\
\hline Postmenopausal bleeding & 2 & $1.90 \%$ \\
\hline
\end{tabular}

Second most common clinical diagnosis for abdominal hysterectomy was dysfunctional uterine bleeding in 27 $(25.71 \%)$ women. $6(5.71 \%)$ cases were preoperatively diagnosed as adenomyosis (Table 3 ).

Table 3: Distribution according to clinical indication.

\begin{tabular}{|l|l|l|}
\hline Clinical diagnosis & Cases & Percentage \\
\hline Leiomyoma uterus & 51 & $48.57 \%$ \\
\hline Dysfunctional uterine bleeding & 27 & $25.71 \%$ \\
\hline Postmenopausal bleeding & 2 & $1.90 \%$ \\
\hline Ovarian cyst & 4 & $3.80 \%$ \\
\hline PID & 2 & $1.90 \%$ \\
\hline Ovarian mass & 9 & $8.57 \%$ \\
\hline Adenomyosis & 6 & $5.71 \%$ \\
\hline Endometrial hyperplasia & 4 & $3.80 \%$ \\
\hline
\end{tabular}


Table 4: Histopathological diagnosis

\begin{tabular}{|l|l|l|}
\hline Histopathological report & $\begin{array}{l}\text { No. of } \\
\text { cases }\end{array}$ & Percentage \\
\hline Leiomyoma & 53 & $50.48 \%$ \\
\hline Adenomyosis & 23 & $21.90 \%$ \\
\hline Fibroid + Adenomyosis & 4 & $3.80 \%$ \\
\hline Endometritis & 2 & $1.90 \%$ \\
\hline Endometrial hyperplasia & 2 & $1.90 \%$ \\
\hline $\begin{array}{l}\text { Endometrial } \\
\text { adenocarcinoma }\end{array}$ & 2 & $1.90 \%$ \\
\hline Ovarian cyst & 3 & $2.85 \%$ \\
\hline Ovarian tumour & 8 & $7.62 \%$ \\
\hline
\end{tabular}

On Histopathological examination, the commonest pathology, similar to clinical impression, was found to be
Leiomyoma at $50.48 \%(\mathrm{n}=53)$. Adenomyosis $(21.90 \%)$ was detected as Second most common pathology on histopathological examination followed by ovarian tumour $(7.62 \%)$ (Table 4). The correlation between the clinical and histopathological diagnosis with respect to benign uterine pathologies was found to be very good. 96.07\% of the Fibroids diagnosed clinically were confirmed on histopathology as leiomyoma. However, double pathologies of Adenomyosis in 4 cases coexisted. Majority of cases $(62.96 \%)$ pre-operatively diagnosed as DUB were found to have adenomyosis. Histopathological confirmation of pre-operative diagnosis was $89 \%$ for malignancy, $96 \%$ for fibroids, $100 \%$ for adenomyosis, $100 \%$ for pelvic inflammatory disease (Table 5 and Figure 2).

Table 5: Correlation between clinical and histopathological diagnosis.

\begin{tabular}{|c|c|c|c|c|}
\hline Clinical diagnosis & No. of cases & Histopathological report & & Percentage correlated (\%) \\
\hline \multirow[t]{2}{*}{ Leiomyoma uterus } & \multirow{2}{*}{51} & Leiomyoma & 49 & $96.07 \%$ \\
\hline & & Unremarkable & 2 & \\
\hline \multirow{4}{*}{$\begin{array}{l}\text { Dysfunctional uterine } \\
\text { bleeding }\end{array}$} & \multirow{4}{*}{27} & Adenomyosis & 17 & \multirow{4}{*}{$7.40 \%$} \\
\hline & & Leiomyoma & 4 & \\
\hline & & Leiomyoma +Adenomyosis & 4 & \\
\hline & & Unremarkable & 2 & \\
\hline \multirow{3}{*}{ Ovarian cyst } & \multirow{3}{*}{4} & Cystic teratoma & 2 & \multirow{3}{*}{$75 \%$} \\
\hline & & Chocolate cyst & 1 & \\
\hline & & Unremarkable & 1 & \\
\hline PID & 2 & Endometritis & 2 & $100 \%$ \\
\hline \multirow{4}{*}{ Ovarian tumour } & \multirow{4}{*}{9} & Serous-cystadenoma & 5 & \multirow{4}{*}{$88.89 \%$} \\
\hline & & Serous cystadenocarcinoma & 2 & \\
\hline & & Granulosa cell tumour & 1 & \\
\hline & & Unremarkable & 1 & \\
\hline Adenomyosis & 6 & Adenomyosis & 6 & $100 \%$ \\
\hline \multirow[t]{2}{*}{ Endometrial hyperplasia } & \multirow{2}{*}{4} & Endometrial hyperplasia & 2 & \multirow{2}{*}{$50 \%$} \\
\hline & & Endometrial carcinoma & 2 & \\
\hline
\end{tabular}

\section{DISCUSSION}

Hysterectomy is the most common gynecological surgery done in the females worldwide as it provides definitive cure to a wide range of gynecological diseases, both benign and malignant. The indications to perform this major surgery should always be justified and the pathology should be proved histopathologically. This is so because the hysterectomy is a major surgery which has its own physical, economic, emotional, sexual and medical significance to the women. Histopathological analysis and review is mandatory to evaluate the appropriateness of the hysterectomy. In present study, The commonest age group undergoing Abdominal hysterectomies was found to be 41-50 years in our study. This is in accordance with Tamilselvi Ramachandran et al, G Gupta et al, Ranabhat SK et al, Surti HB et al in India where the commonest age group is similar..$^{5-8}$ In a
Nepalese study, the mean age was 46.3 years. ${ }^{9}$ The average parity in our study was three with a range zero to nine. Our finding is comparable with the zero to eleven parity ranged reported in Ibadan, Western Nigeria. ${ }^{10}$ Most common indication for hysterectomy in our study was uterine Fibroid (48.57\%) and dysfundtional uterine bleeding $(25.71 \%)$. The commonest indication was fibroid (34\%), followed by DUB $(26 \%)$ in the study by Shergill SK. ${ }^{11}$ Adelusola KA et al found fibroid as a most common indication in $48 \%$ cases. $^{12}$ Jha $\mathrm{R}$ found that leiomyoma was the indication in $24.9 \%$, ovarian tumour in $14.9 \%$ and DUB in $7.7 \%$ of the cases. ${ }^{9}$ Similar results have been reported by Pokras and Hufnagel. ${ }^{13}$

Diagnosis of dysfunctional uterine bleeding (DUB) was made in $25.71 \%$ cases. However, on histopathological examination, only $7.40 \%$ had finding consistent with the diagnosis of DUB while the rest of the patients operated 
with this pre-operative diagnosis were found to have adenomyosis (17 cases) and leiomyoma (4 cases). These findings were missed preoperatively. DUB is a blanket diagnosis, and inadequate work-up, either due to financial constraints or the pressure of the patient to get the surgery done earlier, leads to such scenario. Various previous studies found that the actual diagnosis confirmed by histopathological examination was missed preoperatively in the majority of cases operated with the preoperative indication of DUB. ${ }^{14-16}$ This result emphasizes the fact the pre-operative diagnosis of DUB should be made only after comprehensive and necessary investigations are done. No significant pathology was detected in $7.61 \%$ patients undergoing hysterectomy.

We found that majority of preoperative diagnoses $96.07 \%$ of fibroid cases were confirmed on histopathology. Similarly Histopathological confirmation of pre-operative diagnosis was $89 \%$ for malignancy, $75 \%$ for ovarian cyst, $100 \%$ for adenomyosis, $100 \%$ for pelvic inflammatory disease. The exception was patients with dysfunctional uterine bleeding in whom pathology like adenomyosis or small fibroids were found on histopathological specimens. Lee NC found that of the 1283 women whom they studied, $80 \%$ of the pre-operative diagnoses were confirmed in the potentially confirmable group. ${ }^{10}$ Miller studied 246 hysterectomy specimens and found that clinical diagnoses were confirmed in $50 \%$ of the cases. ${ }^{17}$

\section{CONCLUSION}

In our study, the most common pathology identified among the hysterectomy specimens was leiomyoma. There was a high correlation when the clinical diagnosis was a fibroid, adenomyosis and ovarian mass, However the clinical and pathological correlation are poor when DUB was the preoperative clinical diagnosis.as any surgical procedure, abdominal hysterectomy is also associated with risk factors, thus indication should be carefully evaluated.

Every hysterectomy specimen should be subjected to histopathological examination because it is mandatory for conforming diagnosis and ensuring optimal management, in particular of malignant disease. A yearly audit should be conducted in every government and private institute to collect data and to analyze the pattern of indications and types of histopathological lesions and pattern of diseases.

Funding: No funding sources

Conflict of interest: None declared

Ethical approval: The study was approved by the Institutional Ethics Committee

\section{REFERENCES}

1. Graves EJ. National Centre for Health Statistics, National hospital discharge survey: annual summary,
1990.Viral health stat (13). 1992:112. DHHS publication PHS 92-1773.

2. Begum J, Talukder SI, Hossain MA. A two years audit of complications of total abdominal hysterectomy at Dinajpur Medical College Hospital Dinajpur. Med Col J. 2008;1(1):14-7.

3. John A, Rock M D, Jhon D, Thompson MD. Telind's operative gynaecology. 1st edition LipincottRavenplace.

4. Qamar-ur-Nisa. Hysterectomies, an audit at a tertiary care hospital. Professional Med J 2011;18(1):45-50.

5. Ramachandran T, Sinha P, Subramanium. Correlation between clinicopathological and ultrasonographical findings in hysterectomy. J Clinic Diagno Res. 2011;5(4):737-40.

6. Gupta G, Kotasthane D, Kotasthane V. Hysterectomy: A clinocopathological correlation of 500 cases. Internet J Gynaecol Obstet. 2009;14:1-5.

7. Ranabhat SK, Shreshta R, Tiwari M. A retrospective histopathological study of hysterectomy with or without salphingoophorectomy specimens. Available at www.cmc.edu.np, 24-9.

8. Surti HB, Zaveri P, Shah CK, Shah NR. Clinicopathological study of hysterectomy cases. biennial journal of GAPM ISSN 0975-3109.

9. Jha R, Pant AD, Jha A, Adhikari RC, Syami G. The histopathological analysis of hysterectomy specimens. J Nepal Med Assoc. 2006;45(163):283-90.

10. Lee NC, Dicker RC, Rubin G, Oray HW. Confirmation of the preoperative diagnosis for hysterectomy. Am $\mathbf{J}$ Obstet Gynecol. 1984;150(3):283-7.

11. Shergill SK, Shergill HK, Gupta M, Kaur S. Clinicopathological study of hysterectomies. J Indian Med Assoc. 2002;100(4):238-9.

12. Adelusola KA, Ogunniyi SO. Hysterectomies in Nigerians; histopathological analysis of cases seen in Ile-Ife. Niger postgrad med J. 2001;8:37-40.

13. Pokras R, Hufnagel VG. Hysterectomy in the United States, 1965-1984. AJPH1988;78:852.

14. Nausheen F, Iqbal J, Bhatti FA, Khan AT, Sheikh S. Hysterectomy: the patient's perspective. Ann Gyne. 2004;10:339-41.

15. Tiwana KK, Nibhoria S, Monga T, Phutela R. Histopathological Audit of 373 nononcological hysterectomies in a teaching hospital. Patholog Res Int. 2014;2014:468715.

16. Siwatch S, Kundu R, Mohan H, Huria A. Histopathological audit of hysterectomy specimen in a tertiary care hospital. Sri Lanka J Obst Gynae. 2012;34:155-8.

17. Miller NF. Hysterectomy: therapeutic necessity or surgical racket? Am J Obstet Gynecol. 1946;51:804.

Cite this article as: Yadav DP, Yadav R, Bhati I. Abdominal hysterectomy: analysis of clinicohistopathological correlation in Western Rajasthan, India. Int J Reprod Contracept Obstet Gynecol 2017;6:1012-5. 